\title{
The Nightcrawler, The Wedge, AND THE BLOODIEST RELIGION
}

On New Year's Day 2011, the online conservative news outlet WorldNetDaily (WND) blared this headline: "From Darwin to Marx to Kinsey to Obama." The author was Dave Welch (1961-), head of the Houston Area Pastors Council and a former national field director for Pat Robertson's Christian Coalition. Welch was reacting to the news that President Obama was "evolving" toward approval of gay marriage. According to Welch, Obama and Vice President Biden had a secret "agenda," which was to carry out a "dialectic Marxist strategy" to "overturn traditional morals." There was a "direct linkage" between Marx and Darwin-"Marx and Engels based their communistic philosophy squarely on the foundation of evolutionism." Sex researcher Alfred Kinsey was a devoted Darwinist. As the result of this godless conspiracy, the economy was becoming socialist, and sexual morality and marriage were headed in the direction that "Darwin, Kinsey and their ilk intended." Invoking the Frankish Catholic hero of the battle of Tours, Welch bemoaned the failure of American conservatives to serve as "spiritual, moral, and intellectual Charles Martels 
against the hordes of 'Moors' sweeping through our land." (Welch also referred to the Marxist movement as a "jihad.") Welch then harked back to the biblical prophet Nehemiah, who acknowledged that the Jewish people had abandoned the ways of the true God and that He had justly punished them for their "evil deeds." It was time, Welch wrote, for God's pastors and people to "restore His righteousness to our land."1

Neither historians nor pro-evolutionist academics in any field were likely to take Welch's plot involving Marx, Darwin, Kinsey, and Obama seriously. The anonymous pro-evolutionist blogger who goes by the name of "the Sensuous Curmudgeon"-and is widely respected by academic pro-evolutionists-described Welch's article as a "towering monument of foolishness." ${ }^{2}$ He called WND (which received the Curmudgeon's "Buffoon Award" in 2008) "an absolutely execrable, moronic and incurably crazed publication." ${ }^{3}$ Founded in 1997 by journalist Joseph Farah, a "birther" activist who helped publicize the charge that Obama was not a US-born citizen, WND is far enough to the right that first-time liberal visitors to its website have trouble believing it is not a hoax. ${ }^{4}$

But as "crazed" as Welch's ideas might seem to some, they surely struck a chord for others. Conservative Christian leaders had been teaching about the tie between Marxist philosophy, Darwinian evolution, and sexual immorality for at least a century. To be sure, the context was changing rapidly. The Soviet Union was long gone. A decade of the "war on terror" in Iraq, Afghanistan, and elsewhere had made "jihad" a household word. Welch contended with America's first African American president. Gay rights were ascendant. The Internet vastly multiplied the potential sources of political and moral authority. Due in part to the grassroots conservative activism pioneered by Welch's former employer Pat Robertson, the Republican Party had become "God's Own Party." Conservative evangelicals had a seat at the political table like never before. At the same time, opposition to evolution was increasingly likely to skirt the realm of "creation science" and instead take the form of a seemingly nonreligious "intelligent design" (ID). For all of the ways in which the world had evolved, however, the end of the Cold War did not quash the persistent appeal of Red Dynamite political rhetoric in the new millennium. That rhetoric came in varied forms-the writings of Summit Ministries' David Noebel; the procapitalist politics of the Discovery Institute, the new ID think tank; and 
the continuing creationist campaigns of the ICR and of the new kid on the block, Answers in Genesis.

Given the pivotal role of the Christian Coalition in transforming the Republican Party into a viable vehicle for Christian conservatism, we begin with a man who was no stranger to the allied evils of evolution and communism: Marion Gordon "Pat" Robertson (1930-). The son of southern segregationist US Senator Willis Robertson (R-VA), Pat grew up in Lexington, Virginia, and attended the McCallie prep school in Chattanooga, close on the heels of Genesis Flood coauthor John C. Whitcomb Jr. Robertson graduated magna cum laude from his hometown college of Washington and Lee and then received his JD from Yale Law School. Ordained a Baptist minister after attending the Biblical Seminary in New York, he began to imbibe a strong dose of the Christian charismatic tradition, with its strong emphasis on faith healing and speaking in tongues. Robertson founded the Christian Broadcasting Network in 1960. By the late 1970s he had become a major Christian media mogul and TV personality, seen by millions weekly on The $700 \mathrm{Club} .^{5}$

Until the mid-1970s, Robertson hewed to his father's conservative Democratic sympathies and had high hopes for the newly elected Southern Baptist president, Jimmy Carter. But Carter's liberal politics pushed Robertson to the right. Robertson spoke out against abortion on The 700 Club. His newsletter, Pat Robertson's Perspective, aired his support for Anita Bryant's campaign against gay rights. In 1980, Robertson campaigned for Ronald Reagan and organized a giant "Washington for Jesus" rally in the nation's capital. After Reagan's election, Robertson lobbied hard for a proposed constitutional amendment to allow prayer in public school. Though the amendment failed to secure passage in 1984, Robertson gained increasing attention from Christian conservatives. A televised speech Robertson gave in 1986 effectively launched his 1988 presidential campaign and, through it, the Christian Coalition. Speaking at Constitution Hall in Philadelphia, on the 199th anniversary of the document's adoption by the delegates to the Constitutional Convention, Robertson made a promise: if three million registered voters would sign petitions in the coming year pledging their support to Robertson, he would run for president. ${ }^{6}$ 
Robertson hailed the wisdom of the nation's founders who created a country "under God." He bemoaned the state of America, which in the previous quarter-century had strayed from "our historic Judeo-Christian faith." Public schools had replaced moral absolutes with "values clarification" and "situation ethics." They had replaced the "Holy Bible" with the familiar pantheon of communist and evolutionary evil: Charles Darwin, Karl Marx, Sigmund Freud, and John Dewey. Young people were learning that "if it feels good, do it." For conservative Christians paying attention to the warnings of Francis Schaeffer, Tim LaHaye, and the like, the "whirlwind" of immoral consequences was also familiar: one million teenage pregnancies and four hundred thousand abortions each year; a massive number of sexual assaults; and an epidemic of sexually transmitted diseases, including AIDS.

To save the children, Robertson called for tougher measures on drugs and alcohol in the schools; removal of control of education from the "leftist" teachers' unions; the return of God to the nation's classrooms; and the replacement of "progressive education" with a focus on the "facts" of history, geography, and science. ${ }^{7}$ Robertson got his three million signatures. But his campaign quickly spiraled downward. The marginality of Robertson's Christian charismatic leanings and a series of sex scandals involving former supporters and associates of Robertson doomed his campaign. Still, the essential message-that the Christian "worldview" was under attack and needed to be aggressively defended-had serious staying power for conservative Christians in post-Cold War America.

Dave Welch, the Houston pastor who linked Darwin, Marx, Kinsey, and Obama, found Robertson's message compelling. Welch's story helps us appreciate the worldview of a twenty-first-century conservative Christian activist. Born in Seattle, Welch grew up in coastal Hoquiam, Washington, where his mother took care of the large family, and his father, Herb Welch, a fourth-generation logger, worked as an independent small "gyppo" operator. That label originated as a derisive term for strikebreakers by organizers for the radical Industrial Workers of the World (IWW), who built a logging local of their union in Hoquiam in the early twentieth century. ${ }^{8}$ Herb Welch's politics were far to the right of the IWW. He was active in the local chapter of the John Birch Society, and Dave Welch recalls reading Birch material as a teenager. It included None Dare Call It 
Conspiracy (1972) by Gary Allen, a conservative journalist, Birch Society member, and former writer for George Wallace's 1968 presidential campaign. ${ }^{9}$ In a slim paperback complete with explanatory diagrams, Allen argued that communism was just a front for diabolical conspiracy by a group of "power-mad billionaires" called the "Insiders" whose history reached back to Adam Weishaupt and the Illuminati. One contingent of them were Jewish bankers, though Allen ambiguously cautioned against imputing Insider status to all Jews. The victims of the conspiracy were the middle class-including small businessmen like Herb Welch-who were squeezed from below by "schoolboy Lenins and teenage Trotskys" and oppressed from above by the Rothschilds, the Rockefellers, and the Council on Foreign Relations. ${ }^{10}$

Dave Welch entered electoral politics at age nineteen when he voted for Ronald Reagan in 1980. Over the next fourteen years, Welch became a small businessman like his father, taking over his father-in-law's service station and auto repair business. In 1984, he attended his first Republican gathering and was elected as a county delegate to the state convention. The issue of abortion- "the sanctity of life"-drew him into Republican politics. In 1988, he joined the Pat Robertson campaign. As Welch recalls, Robertson "linked the godlessness, the atheism of communism very much to the policies and the tyranny of communism that go hand in hand." Robertson shared Gary Allen's conspiratorial views. Railing against George H.W. Bush's "globalist" politics in the aftermath of the Gulf War, Robertson explained history as a plot masterminded by the Illuminati, Jewish bankers, and other shadowy figures in The New World Order (1991). ${ }^{11}$ Dave Welch's 2011 piece on Darwin, Marx, Kinsey, and Obama had a similar conspiratorial tone. His allegation that Marxists aimed to overturn morals, "create chaos and then serve as savior," suggests, with echoes of the Protocols, that they were secretly plotting behind the scenes.

The Christian Coalition emerged out of the promise and failure of the Robertson campaign. Welch served as state director and then national field director starting in 1997. He worked closely with history PhD Ralph Reed, whom Welch regarded as "a masterful strategist." Welch tried to follow Reed's methodical model when he formed his own organization in Houston in 2003, the US Pastor Council (USPC). Welch concentrated on local politics and building up strength from the grass roots. As he 
described his approach to local pastors, "'We're going to teach you how to organize a precinct,' but ultimately, 'We will give you the information historically, biblically, politically as to how to be well prepared to do that.'" The information packet Welch put together included step-by-step instructions, an organizational chart, and a summary of the AMERICA plan. "A" stood for "Articulate a Biblical position on important issues of the day": abortion, gay marriage, sexual immorality, creation/evolution, and "Socialism/Marxism vs. Constitutional Republic." To these Welch added "Race Relations and Equal Justice," in an attempt to broaden the base of the US Pastor Council's operation in Houston. ${ }^{12}$

While Welch had no scientific training, his political education had taught him that evolution was "the question" underlying the war of the worldviews. Pointing to the writings of Francis Schaeffer, David Noebel, Tim LaHaye, and D. James Kennedy as resources for his recruits, Welch took up the challenge of explaining to his local preacher allies why the seemingly academic issue of evolution was so important. ${ }^{13}$ "If we assume that we're an animal," he explains, "then the truth is that we don't have a real case to stand on for developing any kind of framework of laws" based on true, Christian morality. This is where "we connect the dots," said Welch: the evolutionary assumption "can produce things like communism which are based on the state being the supreme authority, not God."14 Any pastor who embraced any form of evolution "is no more a Christian than the chimpanzees from which he or she claims to have evolved." 15 In his own distinctive way, Welch carried forth the ideas linking Darwin and Marx that George McCready Price outlined a century earlier.

When it came to the topic of evolution and communism in the early twentyfirst century, there was no greater dot connector than the old anticommunist warrior David Noebel. By the 1980s, Noebel's Anti-Communist Youth University had reinvented itself as Summit Ministries. Summit received a boost in 1987 when a young man named Ryan Dobson attended its summer camp. His father was James Dobson, the doctor who headed up the prominent conservative Christian group Focus on the Family, headquartered a few miles from Summit, in neighboring Colorado Springs. When Dobson promoted the value of his son's experience at Summit on his Focus on the Family radio show, the Summit staff received nearly fourteen thousand new applications. The "explosion" ignited by 
Dobson's promotion resulted in a major expansion of the Summit property in Manitou Springs. It brought welcome publicity for what had been begun by "Doc" Noebel as a modest undertaking more than two decades earlier. ${ }^{16}$

Summit's new success also motivated Noebel to consolidate his nearly thirty years of teaching material into a beefy 891-page textbook, Understanding the Times: The Religious Worldviews of Our Day and the Search for Truth (1991). The book eventually sold more than half a million copies. It carried back-cover endorsements from James Dobson, D. James Kennedy, and Tim LaHaye. The original edition compared three worldviews: Christian, secular humanist, and Marxist/Leninist. Noebel added "cosmic humanist" (New Age-ism) for the 1995 edition and then Islam and postmodernism starting in 2006. In all versions, readers learned how competing worldviews taught about theology, philosophy, ethics, biology, psychology, sociology, law, politics, economics, and history. For its breadth and depth of coverage it was an impressive piece of work. Noebel's confidence in his own Christian worldview was admirable. In the first edition, he encouraged students to prepare for absorbing the material in Understanding the Times (UTT) by reading key texts from all three viewpoints: the Communist Manifesto, the Christian Manifesto, and the Humanist Manifestos I and II. Noebel's confidence was also reflected in the fact that he consciously adopted an evenhanded tone, refusing to portray Marxists or humanists as "either stupid or insane" despite what he claimed, with some accuracy, was "their tendencies to describe Christians in such unflattering terms." 17

In his opening chapter, "The Battle for Hearts and Minds," Noebel made it clear why it was crucial for America's young Christians to grasp the essentials of competing worldviews. Quoting from Children at Risk, by James Dobson and Gary Bauer, Noebel affirmed that Americans were in the midst of fighting "a great Civil War of Values," what Patrick Buchanan would label a "cultural war" the following year at the Republican National Convention. The widespread ignorance among young Christians of worldview fundamentals meant, in Noebel's evocative phrase, that they "stood intellectually naked before left-wing professors." The Cold War might have ended, Noebel acknowledged, but as Fred Schwarz had taught, the campuses continued to be the "nurseries of communism." For all the similarities between secular humanism and Marxism, the latter, in 
Noebel's estimation, was more consistent and stood on a stronger philosophical foundation. As Noebel had been explaining to legions of young Christians in Manitou Springs, if they followed the example of the sons of Issachar from 1 Chronicles 12 and understood the world around them, they would "know what Israel ought to do." The book was both an intellectual exercise and a call to action. ${ }^{18}$

If some youngsters at a Summit summer session might be forgiven for missing the connections between evolutionism and Marxism, no one who persevered through UTT could fail to understand what George McCready Price had meant in 1925 when he called Darwinism "Red Dynamite." Even one of the handful of political cartoons that adorned the text of the original edition emphasized the point: public school students enjoying a field trip to the "Land of Ideas" are free to climb the trees labeled "Karl Marx," "Charles Darwin," "John Dewey," and "Voltaire" but are prevented from visiting "Religion," which is "Off Limits." In every one of the ten chapters on the Marxist worldview, evolutionary theory made a prominent appearance. In the opening summary of his treatment of Marxist philosophy, Noebel concluded that "for better or worse, the Marxist's philosophy of dialectical materialism is built primarily on the 'science' of Darwinian evolution." In outlining Marxist ethics, Noebel devoted an entire section to "The Evolution of Morality." His discussion of Marxist psychology leaned heavily on the ideas of Ivan Pavlov, "an avowed evolutionist." On Marxist sociology, Noebel quoted Lenin on society as "a living organism" in a section titled "Society as an Evolving Entity." The "Marxist evolutionary perspective" provided a framework for analyzing history and law. Most extensively, a twenty-six-page chapter on Marxist-Leninist biology wove multiple threads between Marx, Engels, Lenin, and evolutionary science. Six of those pages were devoted to punctuated equilibrium and Stephen Jay Gould, with an obligatory comment about his "daddy's knee."19

No one knows how many teenagers powered through all forty-two chapters of the abridged edition of UTT. But Noebel and Summit did make a considerable effort to reach young people. The 1995 abridged edition omitted endnotes and featured large, easy-to-read pull quotes, photos, and concise timelines of the lives of important figures. The 2006 edition was still in black and white but included many more text boxes with quotes and definitions of key terms, a more attractive layout, and a 


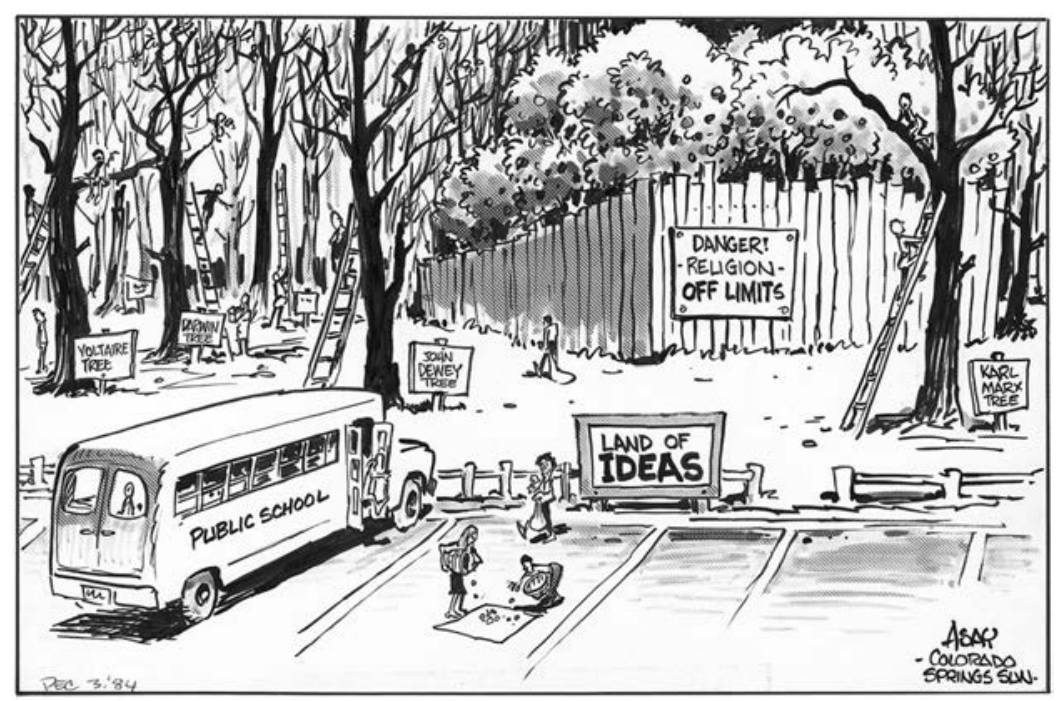

Figure 13. "Land of Ideas" cartoon, 1984. Appearing in anticommunist David Noebel's pioneering worldview textbook Understanding the Times (1991), the cartoon helped readers understand the twin threats of Marxism and Darwinism. Originally published in the Colorado Springs Sun, December 3, 1984. Cartoon by Chuck Asay. Courtesy of Special Collections, Pikes Peak Library District, Colorado Springs, CO, MSS 0448.

regular feature called "The Pop Culture Connection." In the chapter on Marxist-Leninist biology, Noebel supplemented his discussion of punctuated equilibrium by means of a scene from X-Men 2. Whereas evolution usually moves slowly, explains character Dr. Jean Grey, sometimes it "leaps forward," producing a range of "mutant" characters. Young viewers of the film might remember characters like Nightcrawler. He has twotoed feet, three-fingered hands, yellow eyes, and a prehensile tail-not exactly what Gould and Eldredge had in mind, but surely fodder for a lively conversation. ${ }^{20}$

In many cases, that conversation would have taken place outside of the nation's public schools. The publication of UTT coincided with a meteoric rise in both private Christian schools and conservative Christian homeschooling. The Christian school movement started by Tim LaHaye and others in the 1960s and '70s had gone mainstream. The copublisher of the 1995 edition of UTT was the Colorado Springs-based Association 
of Christian Schools International (ASCI), the largest national accrediting organization in the field. Between 1983 and 2005, the number of ASCI schools jumped from 1,900 to 3,957 , with a consequent rise in student enrollment from 270,000 to $746,681 .{ }^{21}$

Christian homeschooling provided a ready market for Noebel's book. Based on the pioneering ideas of R.J. Rushdoony and the legal activism of John Whitehead and Michael Farris, homeschooling became legal in all fifty states by the early 1990s.22 Summit produced a UTT homeschooling package, which included the 2006 revised second edition, teacher and student manuals, and eight DVDs. In her review of the new package, popular conservative homeschooling book reviewer Cathy Duffy opined that she was "so impressed with the course that I think it or a similar course should be offered to (or maybe even required of) all Christian teens and parents." 23

Noebel's efforts to reach the Christian masses drew strength from a continuing collaboration with Henry Morris and the ICR. During the 1990s, Manitou Springs was a regular stop for the ICR's traveling lecturers in the Summer Institute on Scientific Creationism. ${ }^{24}$ Like Noebel, the ICR continued to emphasize the political and moral "fruit" of evolutionary thinking, including its communist component. Most prominently, this took the form of the third volume of the Modern Creation Trilogy (1996), coauthored by the father-and-son team of Henry and John Morris. Titled "Society and Creation," it recast the material from Long War against God in a shorter, updated form. After tracing evolution to Babel and Satan, the Morrises offered by-now familiar material in two key chapters on "The Corrupt Fruits of Evolutionism" and "Evolution and Its Deadly Social Philosophies." Marx's supposed Satanism was now relegated to a footnote, but the twelve-page section on Marx and evolution unfortunately repeated the thoroughly discredited claim that Marx wanted to dedicate Das Kapital to Darwin. ${ }^{25}$

As a front-page article in Acts \& Facts noted, the appearance of the Trilogy as a boxed set was "an unusual publishing event." ${ }^{26}$ There is no evidence to suggest that it sold well. But as before, the ICR was not content only to write about evolution's fruits. In the summer of 1995, John Morris visited fundamentalist Baptist Pensacola Christian College (PCC) to give a series of Trilogy-themed talks. Founded by Bob Jones University graduates Arlin and Beka Horton in 1974, PCC was committed to a 
young-earth creationist perspective. Its publishing arm A Beka Books was a leading supplier of conservative Christian curriculum materials. John Morris's third lecture, given to some three hundred graduate students at PCC, concerned "how evolution has brought a host of evils upon society." 27 Trilogy may have been a marginal contributor to the ICR's revenue stream. But Morris's visit to PCC reminds us that the ICR was part of a network of conservative activists who made a significant impact on the education that millions of young Christians would receive.

As the ICR continued to spread its fruitistic worldview, creationism was evolving. Under the leadership of the Discovery Institute, founded in Seattle in 1990, the new buzzword for those opposing evolutionary science was no longer the Morris-spawned "scientific creationism," but rather "intelligent design." ID seemed worlds away from the young-earth perspective. Its promoters denied that it relied on biblical authority for its conclusions or harbored any political aims. Both claims were deceptive. In its own distinctive way, the Discovery Institute and its campaign for ID are a twenty-first century continuation of the Red Dynamite tradition.

In the hands of biochemist Michael Behe, mathematician William Dembski, philosopher of science Stephen C. Meyer, and law professor Philip Johnson, ID offered a scientific-sounding challenge to Darwinian evolution. The poster child for ID was the bacterial flagellum-a whiplike structure whose functioning depended on a set of intricately interdependent parts-which, Behe argued, could not have evolved gradually, as Darwin claimed. The flagellum, in Behe's terms, was "irreducibly complex" and so must have an intelligent designer. ID's approach relied on the argument from design that William Paley had proposed almost two hundred years earlier. But ID proponents' credentials and careful excision of explicitly religious references gave the impression of a bold new direction. ${ }^{28}$

The nerve-center for ID was a far cry from Henry Morris's ICR. Formed initially as a branch office of the Indianapolis-based Hudson Institute, a conservative think tank formed in Croton-on-Hudson, New York, by RAND Corporation employees, the Discovery Institute was the brainchild of liberal Republicans Bruce Chapman and George Gilder. Their coauthored book, The Party That Lost Its Head (1966), bemoaned the ultraconservatism of Barry Goldwater and his supporters in the John 
Birch Society. Later the two moved to the right, Chapman as a Reagan appointee and Gilder as one of the intellectual inspirations for Reagan's supply-side economics policies. ${ }^{29}$ In its early years, the Discovery Institute took on a range of projects, including one on transportation networks in the Pacific Northwest funded heavily by the Bill and Melinda Gates Foundation. Not until 1993, when Chapman read a pro-ID piece by Cambridge PhD Stephen Meyer, did it wade into the waters of the evolutionary controversy.

Meyer's article came to the defense of young-earth creationist Dean Kenyon, a professor at San Francisco State University with a PhD in biophysics. Won over to young-earth creationism in 1970s, Kenyon offered expert creationist testimony in the McLean v. Arkansas and Edwards v. Aguillard cases. During the latter case, he authored a creationist textbook, Of Pandas and People, published two years later in 1989. Kenyon routinely included creationist material in his San Francisco State biology class, and in 1992 was ordered to cease and desist by his department chair. Kenyon appealed on the grounds of academic freedom and won the right to keep teaching. Meyer branded the whole affair a "Scopes Trial for the '90s." 30

Championing the ID cause, Meyer was at pains to emphasize that intelligent design was not a form of creationism. As he told neoconservative talk show host Ben Wattenberg on the PBS show Think Tank in 2006, intelligent design involved an "inference from biological data, not a deduction from religious authority." 31 Despite Meyer's protestations, the 2005 Kitzmiller case in Dover, Pennsylvania, had already blown a large hole in the claim that Bible-based creationism was not implicated in ID. The Dover school board had required biology teachers to introduce intelligent design through Kenyon's Of Pandas and People. Doing research for the plaintiffs in the original proofs of Pandas, pro-evolutionist philosopher Barbara Forrest discovered an intriguing pattern. After the Edwards ruling made teaching creationism unconstitutional, Kenyon's team had searched and replaced every instance of "creationists" with the seemingly nonreligious phrase "design proponents." The smoking gun that tipped her off was the one instance where the transformation misfired, rendering "creationists" as "cdesignproponentists." This "missing link" was one of many facts introduced at trial that led Judge John Jones III, a Republican appointed by President George W. Bush, to comment in his ruling that the school board had acted with "breathtaking inanity." 32 
Even before Kitzmiller, it was clear the Discovery Institute had not only religious inspiration but also a political vision straight out of the ICR creation museum. True, chief ID ideologist Philip Johnson distinguished his conception of "creationism" from young-earth "creation-science." Johnson thought the earth might be ancient, and he even held the door open to a God-directed evolution. But he joined Henry Morris in pinning a range of moral evils on the dominant philosophy of "evolutionary naturalism and materialism." These included easy divorce, single parenting, the "sexual revolution," radical feminism, and gay liberation. ${ }^{33}$ While Johnson consciously steered away from explicit theological arguments, he did employ a tree metaphor that meshed with the "fruits" of Matthew 7:15 and was remarkably similar to the Santee museum exhibit. Johnson used the allied metaphor of the "wedge" to describe the way in which ID could "split" the apparently "solid log" of "scientific materialism." 34

Johnson's political logic also led to the demonization of the unholy materialist trio identified by his conservative predecessors: Darwin, Marx, and Freud. In his first book, Darwin on Trial (1991), Johnson gave ample space to Karl Popper's critique of Marx and Freud; they were unscientific since their systems of thought were not falsifiable. Johnson suggested that Darwin should be added to the mix as yet another proponent of "pseudoscience." ${ }^{35}$ In Defeating Darwinism (1997), Johnson applauded the fall of Marx and Freud and predicted that "Darwin is next on the block." Unlike Henry Morris, Johnson did not take the trouble to show how intimately Marx and Darwin were connected. But he did celebrate the fall of the Soviet Union as an example of how "a cultural tower built on a materialist foundation can look extremely powerful one day and yet collapse in ruins the next." ${ }^{36}$

To accelerate the collapse of Darwinism, Johnson and others organized a conference in 1995 called "The Death of Materialism and the Renewal of Culture." There they refined their "wedge" strategy to split the Darwinist materialist tree. As Bruce Chapman explained—and as Dan Gilbert would have appreciated-the conference prepared the group to take on "the ideology of materialism and the host of social 'isms' that attend it." In 1996, Johnson and others established the Center for the Renewal of Science and Culture (CRSC), under the auspices of the Discovery Institute, to carry out this grand goal. One of the primary funders of the CRSC, to the tune of $\$ 1.5$ million, was multimillionaire Howard Ahmanson Jr., to 
whom Philip Johnson dedicated Defeating Darwinism (1997). Heir to the Home Savings of America fortune, Ahmanson was a Christian Reconstructionist who until 1995 had sat on the board of R.J. Rushdoony's Chalcedon Foundation and provided key funding to conservative Christian attorney John Whitehead. As Ahmanson explained his philanthropic goal, "My purpose is total integration of Biblical law into our lives." 37 Aware of Ahmanson's Reconstructionist leanings, Johnson was careful to disclaim any interest in a Christian "political party." 38 These qualms, however, did not prevent Johnson from speaking in 1999 at fellow conservative Presbyterian and Reconstructionist D. James Kennedy's Reclaiming America conference. ${ }^{39}$

The "spiritual and intellectual movement" preferred by Johnson was inevitably political. This fact emerged clearly from an initially secret CRSC five-year public relations plan leaked online in 1999-the "Wedge Document." ${ }^{40}$ It began by affirming that the major elements of "western Civilization"- "representative democracy, human rights, free enterprise, and progress in the arts and sciences"-were based on the idea that human beings are created in the image of God. It then claimed that this idea had been undermined for more than a century by the chief advocates of the "materialist conception of reality," Darwin, Marx, and Freud. They viewed people not as "moral and spiritual beings" but rather "as animals or machines who inhabited a universe ruled by purely impersonal forces and whose behavior and very thoughts were dictated by the unbending forces of biology, chemistry, and environment." This worldview created "cultural consequences" that were "devastating" in a number of arenas: the teaching of social sciences, which held the environment responsible for individual behavior, thus removing any sense of objective moral standards; modern approaches to criminal justice, product liability, and welfare, all of which promoted a "victim" mentality; and "utopian" and "coercive" political projects pushed by "materialist reformers" who "promised to create heaven on earth." ${ }^{41}$

To fell the tree of materialism with the wedge of intelligent design, the document's authors proposed three phases of activity: research/writing, publicity, and "Cultural Confrontation and Renewal." Commenting on their document after it became public, Discovery Institute leaders denied any political aim. The institute was not seeking to establish a "theocracy" but rather to influence "science and culture" with "ideas." And yet, the 
chief "governing goal" listed in the document is "to defeat scientific materialism and its destructive moral, cultural and political legacies." Since those "legacies" included not just ideas but social and political practicessuch as welfare or product liability law- "renewal" necessarily meant changing power relations between groups of people. It was not just that the Discovery Institute would go on to lobby for changes in state laws to allow for the teaching of intelligent design. It was taking part in the "culture war" over who ruled America. ${ }^{42}$

The document's emphasis on "free enterprise" as a product of belief in God, paired with its anti-Marxism, was an important-and often unrecognized-component of the Discovery Institute's political agenda. In 2009, Jay Richards, a Discovery Institute senior fellow and early leader of the CRSC, published Money, Greed, and God: Why Capitalism Is the Solution and Not the Problem. As he noted in his introduction, the United States may have won the Cold War, but "Just turn on the TV and you'll see capitalism blamed for almost every social problem." "43 Given a decade of corporate scandals and then the Great Recession of 2008, this was no surprise. In the face of growing anticapitalist sentiment, Richards offered an updated Carl McIntire-esque paean to free enterprise-complete with biblical quotations-for the twenty-first century. Defending intelligent design and critiquing evolutionary science, as it turns out, also meant defending capitalism.

If intelligent design creationism seemed well adapted to the political and legal environment of the new millennium, it hardly spelled the end of ICRstyle "scientific creationism." It, too, evolved with the times and starting in 1994 took the form of a new organization spawned from the very loins of the ICR. Within the next two decades, Ken Ham's Answers in Genesis (AiG) left its creationist parent in the dust. Having started his American creationist career in the 1980s leading the ICR's Back to Genesis seminars, Ham sharpened his populist focus, established a highly successful website (over forty million page views by 2014), produced a shiny new magazine, Creation (later renamed Answers), set up shop in northern Kentucky, and in 2007 welcomed the first visitors to AiG's \$27 million Creation Museum. By 2019, more than four million people had walked through the museum's doors. ${ }^{44}$ In the summer of 2016, AiG opened the first installment of a planned Ark Encounter theme park, within an hour's 
drive of the museum. Costing over $\$ 100$ million and featuring a 510-foot ark, the park exhibit was expected to draw two million visitors in its first year of operation alone. ${ }^{45}$ AiG's essential young-earth creationist message was the same one that Henry Morris and John Whitcomb Jr. had purveyed in The Genesis Flood more than thirty years earlier: the earth was about ten thousand years old. Evolutionary ideas had devastating consequences. And one of these satanic consequences was communism, though its role was considerably reduced in Ken Ham's reformulation.

An early indication that Ham would be applying Morris's "fruit test" arrived in the wake of the tragic events at Columbine High School in Littleton, Colorado. On April 20, 1999, students Dylan Klebold and Eric Harris-the latter wearing under his trench coat a T-shirt bearing the words "NATURAL SELECTION"-gunned down twelve students and one teacher. Leading up to the shootings, Harris had ranted online about the need to cull the unfit from the human population. ${ }^{46}$ In a statement on the AiG website nine days later, Ken Ham suggested that evolutionary education was the "missing link" that could explain the murderous Colorado attacks. Since schools had been teaching that students are "just evolved animals, and that there is no absolute authority," such attacks would continue until the nation "allows God to be the absolute authority." 47 Ham was probably nudged by a broadcast by conservative radio commentator Paul Harvey, who read onto the air a letter to the editor from Addison L. Dawson, a right-wing resident of San Angelo, Texas. Dawson believed that evolution helped to cause the shootings. "Children are taught," Dawson wrote in a style reminiscent of fellow Texan J. Frank Norris, "that they are nothing but glorified apes who have evolutionized out of some primordial soup of mud.” In June of that year, US Representative Tom DeLay (R-TX), the House majority whip, read Dawson's letter into the Congressional Record and immortalized the Texas man's words for a national audience. ${ }^{48}$

AiG's fruitistic perspective was also in evidence in Creation Museum exhibits. While nearly all of the text in the museum concerned either direct biblical apologetics or attacks on the inadequacies of evolutionary science, AiG found other ways to direct visitors' attention to the social and political impact of evolutionary thinking. As millions of people walked through "Graffiti Alley," they saw a hodgepodge of magazine and newspaper clippings pasted to the faux-brick walls. School shootings, gay marriage, 
assisted suicide, cloning, removal of the Ten Commandments from the public square-these all testified to a nation in moral decline. They resulted from the shift from a God-centered absolute standard of morality and truth to a relativistic one where, as a nearby sign declared, "Today Man Decides Truth." To hammer home the relativism, the word "truth" is crossed out with red spray paint and replaced with an artistically graffitied "Whatever." The same political logic was at work in the "Culture in Crisis" room, where visitors could peep, in voyeuristic fashion, into the windows of suburban American homes. In a video playing on a flat screen, wayward youth are seen and heard exhibiting the presumed evil effects of the godless, Darwinian worldview: violent video games, pornography, drugs, teen pregnancy, abortion, parental neglect, and alcoholism. ${ }^{49}$ These exhibits may have made up a small portion of the Creation Museum, but they stood at the center of its mission. Ultimately, AiG aimed to mobilize visitors for right-wing political action. ${ }^{50}$

If AiG underplayed its worldview politics at the Creation Museum, this was not the case in other venues, where Ken Ham and his compatriots were clear about the worldly stakes in the debate over "origins." At the Answers in Genesis Mega-Conference in July 2013, a key focus was the recent pair of US Supreme Court decisions (United States $v$. Windsor and Hollingsworth v. Perry) upholding the right of gay marriage. In his talk, Tony Perkins of the Family Research Council urged his audience not to be discouraged, because "that's what our adversary the Devil wants." 51 Even when the explicit conference focus was evolutionary science, politics always lurked nearby. One afternoon, the roughly one thousand attendees were treated to the world premiere of Evolution v. God (2013). The film uses man-on-the-street interviews on a secular college campus to "expose" the fact that none of the science students or professors interviewed, despite their belief in evolution, could say that they actually had "seen" evidence of "macro-evolution" taking place, from, say, dogs to whales. ${ }^{52}$ The real meaning of the film, however, emerged in the introduction by filmmaker Ray Comfort. "If atheistic evolution is true," Comfort told the crowd, "and we are past primates with no moral accountability-then fornication is nothing but our species following our instinct to procreate. If Darwinian evolution is true, then adultery, pornography, homosexuality, lust, lying, and blasphemy are culturally acceptable. If there is no God, then anything goes." The film was yet another device to emotionally 
prepare the AiG faithful-in part through the bonding effect of group laughter-to take on these serious "culture war" issues in the political realm. ${ }^{53}$

The same fruitistic dynamic was on display less than a year later, this time before an online audience of millions who watched Ken Ham debate Bill Nye "the Science Guy." ${ }^{54}$ In his opening thirty-minute presentation, Ham began by appearing to talk about science, but by the end it was clear that he was really talking about politics. Ham focused on the longstanding distinction the ICR and AiG made between "observational" and "historical" science. As he explained, the former treats events taking place in the present so that we presumably can reach solid, reliable conclusions. The latter, however, as it concerns events taking place without human witnesses, cannot lead to objective conclusions. ${ }^{55}$ This then deprives evolutionary science of any privileged status. It is, in effect, another religion, a point resting on the ideological work that John Whitehead, Francis Schaeffer, and Tim LaHaye had done decades before.

Having freed himself from the need to address any details of evolutionary science, Ham now got to the heart of the matter with a slide that illustrated the foundation stones of both evolution and creationism. On the left side was a stack of evolution-inspired bricks labeled "abortion," "euthanasia, "marriage ???," "moral relativism," and "man's ideas/naturalism." On the right side, appropriately, was the creationist stack: "life begins at fertilization," "sanctity of life," "biblical marriage," "moral absolutes," and "God's word." "See," Ham commented, "the battle is really about authority. It's more than just science or evolution or creation; it's about who's the authority in this world. Man or God? If you start with naturalism, then what about morals? Who decides right and wrong? .. . Abortion—get rid of spare cats, get rid of spare kids, we're all animals." ${ }^{56}$ For Ham's audience at the Creation Museum and for his supporters worldwide, this was the political red meat of the debate.

For his part, Bill Nye talked knowledgeably about the Grand Canyon; snow-ice cores in Antarctica; tree rings; Tiktaalik, the amazing half-fish and half-amphibian; and cosmic background radiation. But Nye failed to recognize that he was firing blanks in a political battle. His condescending terms of address- "my Kentucky friends"- did not help. Nye concluded with a vain attempt to connect the battle over evolution to a political issue he thought might appeal to his audience: economic nationalism. If we 
devalue science education, Nye warned, America would fail to compete with its rivals in the world. "We need to innovate to keep the United States where it is in the world," he said. ${ }^{57}$

For all of Ken Ham's relentless focus on the politics of the culture war, he rarely ever brought communism into the picture. In the early twentyfirst century, Ham understood that anticommunism did not carry the same punch. A two-part political cartoon published by AiG in the wake of the Columbine shootings serves as an index of this shift. The first panel, "How to Build a Bomb in the United States Public School System," features a scowling, alienated teenager whose head is a ticking, black dynamite bomb. The accompanying text offers three steps to produce the "bomb" in question: teach evolutionary ideas, take away the Bible, and then "stand back and wait!" To the Sixth Commandment injunction, "Thou Shalt Not Kill," the bomb-headed figure responds, "Why not?!!" In the second panel, a happy, clean-cut Bible-carrying teenager responds to the same question, "I understand!" He has benefited from learning that "people are not evolved animals." Given the long history of associating bomb throwers with anarchists and communists, it is striking that in 1999, the bomb no longer carried explicit political connotations. The link between George McCready Price's "red" and "dynamite" seems to have been severed.

At AiG's Creation Museum-in contrast with the ICR museum in Santee-one searches in vain for any textual reference to Karl Marx (the satanist or not), communism, or socialism. The only explicit political reference even close to this vein-and then a visual and auditory one-comes in the Cave of Sorrows. Visitors pass by a projected still image of a Nazi parade with jarringly loud audio of Hitler speaking. ${ }^{58}$ And yet, the reference to Hitler-given the creationist movement's constitutional inability to distinguish Nazism from communism-turns out to be a clue that AiG had not dropped anticommunism from its creationist arsenal.

Decades after the end of the Cold War, Ken Ham and colleagues continued to find ways to take potshots at the communists. Take, for instance, AiG's response to the 2007 killings at Jokela High School in Finland. ${ }^{59}$ Shooter Pekka-Eric Auvinen was a deeply alienated admirer of Finnish ecofascist Pentti Linkola, who advocates radical human depopulation to save the earth. Like Columbine killer Eric Harris, Auvinen viewed himself 
as a heroic "natural selector" personally eliminating the "unfit" from the human population. ${ }^{60}$ Calling Auvinen a "self-proclaimed Social Darwinist," AiG writer Bodie Hodge repeated the arguments Ken Ham made about Columbine but with a twist. In his evolutionary morality, Hodge argued, Auvinen resembled others who had borne violent "fruits of evolution." Darwin's arguments had influenced not only mass murderer Adolf Hitler, Hodge wrote, but also "Karl Marx, Pol Pot, Leon Trotsky, and Joseph Stalin." Can we afford more "fruit," Hodge asked, like that produced by the "Marxist teachings of Hitler and Stalin"? ${ }^{61}$

Not only was Hitler outnumbered by violent Communist criminals, but he vanished into the Communist woodwork. The vehement opponent of Bolshevism, in Bodie Hodge's hands, miraculously becomes a Bolshevik. In a sense, it was the same logic, driven by political necessity, that led Gerald Winrod to conclude that Franklin Roosevelt was Jewish. But it also drew on a long conservative tradition that equated communism and fascism. Readers of Hodge's article who wanted to know more could click on the hyperlinked names of Marx and associates and read another AiG piece, "Darwin's Impact-the Bloodstained Legacy of Evolution." It damned the communist Darwinians in more detail, though it did distinguish between Marxist class struggle and Nazi "racial" struggle. ${ }^{62}$

In 2009, Hodge followed up with "The Results of Evolution: Could It Be the Bloodiest Religion Ever?" The centerpiece was a table listing the number of deaths caused by the by-now-familiar list of "leaders with evolutionary worldviews": Hitler, Trotsky and Lenin, Stalin, Mao, and Pol Pot. A loose notion of causation led Hodge to attribute all deaths from the following conflicts to evolution: World War I and World War II, including the Holocaust; the Russian Revolution and Civil War; the entire Chinese Revolution; and the Cambodian revolution. (A later edition of this article added the Korean and Vietnam Wars.) To this Hodge added estimates of total abortions-also evolutionary casualties-from a select group of countries over decades-twenty-six million for the US alone from 1928 to 2007. In the twentieth century, the "consequence" of the "idea" of evolution—as lived out by communists, Nazis, and abortionists—was a pile of $778,000,000$ corpses. $^{63}$

Weird as Bodie Hodge's statistical "research" might seem to historians of the twentieth century, the table of casualties was consistent with a 
long-standing line of argument that held up communism as an illustration of evolution's amorality and "culture of death." In the 1920s, William Jennings Bryan pinned the origins of World War I on the evolutionary proclivities of the German General Staff. In the 1950s, John R. Rice pilloried communists for their willingness to cheat and murder. Now came Hodge and AiG to reinforce this idea with a scientific-sounding set of "data." The fact that his first four endnotes cited nothing more than Wikipedia did not matter to the AiG faithful. Hodge had confirmed what they already knew. Anticommunism was a minor weapon in AiG's arsenal. But it was a live one. Hodge's revised article was included in AiG's A Pocket Guide to Atheism (2014, with an introduction by Ken Ham), still offered for sale at the Creation Museum bookstore today. ${ }^{64}$

For a scholarly version of Hodge's anticommunist arguments, AiG collaborated with Jerry Bergman, a Jehovah's Witness turned atheist turned young-earth creationist scholar. The possessor of nine degrees in fields ranging from biology to public health to social psychology, Bergman is a prolific writer, best known as the champion of those who, he claims, have been fired from their jobs or otherwise victimized for challenging the evolution "dogma." ${ }^{65}$ Bergman counts himself among these modern-day reverse John Scopeses (Bergman was denied tenure at Bowling Green State University). He has compared the supposed persecution of creationists in the US to the early stages of Nazi persecution of German Jews. ${ }^{66}$

In "The Darwinian Foundation of Communism," originally published in AiG's Creation magazine in 2001, Bergman argued that the "communist holocaust" of the twentieth century was due in large part to Darwin's influence over Marx, Engels, Lenin, Stalin, and Mao. Bergman was more restrained with his statistics-he estimated that the victims numbered one hundred million, barely one-eighth of Hodge's figure. His writing was also more grounded in research. He accurately traced the impact of Darwin on the early Russian Marxists. He appropriately quoted from Richard Hofstadter on the Darwinian presence in the output of the socialist Kerr publishing house in Chicago. At the same time, Bergman provided a strangely distorted version of Marxist revolutionary theory, in which "the strong overthrow the weak." Fond of loose Hitler analogies, Bergman did little to distinguish Nazis from communists. In one block quote, meant to illustrate the impact of Darwin on Marx, most of the text addressed Hitler's politics. ${ }^{67}$ 
Bergman has also given scholarly cover to the claim, made most loudly by the ICR in its Santee museum, that Darwin is responsible for what Bergman calls "ruthless laissez-faire capitalism." As in the museum, the poster boys are Carnegie and Rockefeller, the classic "social Darwinists" whose choice quotations presumably "prove" Darwin's evil impact on society. ${ }^{68}$ In one incarnation of this argument in his book The Darwin Effect (2014), Bergman describes poor working conditions, low pay, and profiteering, citing as one authority Howard Zinn's A People's History of the United States. ${ }^{69}$ To the uninitiated, Bergman seems to be taking the side of workers and raising the flag of revolution. But as creationists have done since George McCready Price, Bergman instead provides a defense of capitalism using anticapitalist-sounding language. The key is that Bergman never specifies what un-ruthless capitalism looks like. His work suggests, without ever explicitly saying so, that there exists a kinder, gentler, capitalism, compatible with the biblical creationist ideas. Bergman's argument complements the openly pro-capitalist work of Jay Richards over at the Discovery Institute.

Where Bergman leaves the magical realm of ideal creationist capitalism to the imagination, another AiG ally, pastor Chad Hovind, has spelled it all out. The nephew of young-earth creationist Kent Hovind, the former owner of Dinosaur Adventure Land who is now serving time in federal prison for tax evasion, Chad Hovind pastors a church in nearby Cincinnati. ${ }^{70}$ His cousin Eric (Kent's son), a graduate of the Pensacola Christian schools of A Beka Books fame, was one of the featured speakers at AiG's 2013 Mega-Conference. Right outside the main hall, Chad Hovind staffed a booth promoting his new book, Godonomics: How to Save Our Country - and Protect Your Wallet-through Biblical Principles of Finance (2013). With blurbs from former Arkansas governor and presidential hopeful Mike Huckabee, TV and radio personality Glenn Beck, and Christian conservative historian-celebrity David Barton, the book was selling like hotcakes. Featuring chapters like "What Would God Say to FDR about Liberty?" and "What Would God Say to Karl Marx about America?" Hovind's book makes a blindingly positive case for the free enterprise system.

Like Jay Richards, Hovind wrote his book because he perceived that an increasing number of young Christians were rejecting capitalism. In the 
name of "social justice," with references to Jesus's Sermon on the Mount, young people mistakenly "consider socialism to be the economic system that God endorses." Bemoaning excessive government taxation and debt, Hovind cites neoclassical economist Milton Friedman and preaches the values of personal responsibility, generosity, hard work, incentive, and reward. Instead of buying his son a new Xbox, Hovind insisted that the boy earn the money to buy it. For a model employer, Hovind ironically chose the prototype of the ICR's anti-social Darwinist position: Andrew Carnegie. Asked by a reporter how he fostered the personal growth of his employees, Carnegie "said people are developed the same way gold is mined. Tons of dirt need to be moved to find an ounce of gold." But if you focus on the positive potential, your employees will thank you and reach their goals. ${ }^{71}$

When Hovind directly confronted Karl Marx, he not only drew on arguments that Carl McIntire, Raymond Edman, and John R. Rice had made decades before, but he explicitly brought evolution into the picture. In a table titled "Communist Manifesto vs. the Bible," Hovind highlighted the differences between the way Marx and God would answer a series of fundamental questions, such as "Who are we?" Marx: "Humans are a highly evolved animal and are inherently good; in need of a good environment to stimulate good behavior." God: "Humans are spiritual and physical beings made in the good image of God, but possessing a sinful heart that makes us individually responsible for our evil behavior." For readers wanting more, Hovind referred them to Understanding the Times by David Noebel, who is indeed the leading worldview warrior on this issue. $^{72}$

At the 2013 AiG Mega-Conference booth, Hovind not only hawked his book and six-DVD Godonomics course, but handed out, for free, a clever Marx-themed faux credit card to reinforce his message. Adorned with a portrait of Marx, the "Government Master Card" (subtitled the "Spend-Like-There's-No-Tomorrow Card") is issued to "I.M. Enslaved." By refusing God's warnings and spending more than they had, cardholders would find themselves in a state of "serfdom," echoing economist F. A. Hayek's classic anticommunist tract. ${ }^{73}$ While the card made no reference to evolution, Hovind's presence at the conference and the clear references in his book to Marx's evolutionary thinking help to demonstrate how AiG was not merely poking holes in a scientific theory or upholding a 
particular interpretation of the Bible, but engaging in a long tradition of Red Dynamite politics.

As much as David Noebel, Jerry Bergman, and Chad Hovind might seem to be lone voices in the twenty-first-century wilderness, the persistence of creationist anticommunism decades after the end of the Cold War is significant. For a century, Red Dynamite warriors, from George McCready Price to Aimee Semple McPherson to John Rice to Dave Welch, were concerned above all about changing social, political, and moral standards that relied on human rather than divine dictates. The fall of Stalinist regimes in the former Soviet Union and Eastern Europe in the early 1990s put an end to one model of social change but did little to resolve fundamental issues of inequality, exploitation, and injustice worldwide. By 2016, conflicts over these issues shook up the American political system and gave Red Dynamite politics a new lease on life into the Trump era. 